\title{
PENINGKATAN KETERAMPILAN BERBICARA MAHASISWA BAHASA JEPANG MELALUI PENDEKATAN LESSON STUDY DENGAN MENGGUNAKAN MATERI AJAR APRESIATIF
}

\author{
Subandi \\ Universitas Negeri Surabaya \\ banjuchi69@yahoo.co.jp
}

\begin{abstract}
Abstrak: Keterlibatan dan keaktifan peserta didik dalam PBM menjadi permasalahan dalam dunia pendidikan yang selalu muncul. Keterlibatan dan keaktifan peserta didik akan terbantu dengan penerapan pendekatan dan materi ajar yang tepat. Pendekatan Lesson Study yang didukung oleh materi ajar yang apresiatif ini bertujuan untuk meningkatkan keaktifan dan kemampuan khususnya keterampilan berbicara peserta didik. Lesson Study memberikan kesempatan dan peluang kepada peserta didik untuk terlibat langsung secara aktif yang akan membentuk atmosfir positif PBM serta meningkatkan motivasi belajar serta mengkonstruksi pemahaman melalui pengalaman langsung peserta didik. Materi ajar yang apresiatif menjadi perangsang awal untuk membantu peserta didik agar mampu mengawali mengungkapkan gagasan dan pikirannya secara lisan. Hasil akhir membuktikan 93\% peserta didik dapat melakukan presentasi, wawancara, dan percakapan dengan memenuhi aspek-aspek yang tentukan dalam rubrik penilaian.
\end{abstract}

Kata Kunci: kebebasan terkontrol, berpikir tinggi, pemancingan

\begin{abstract}
Active participation of students in the process of learning and teaching will always become a problem in educational world. This will be easily carried out by applying appropriate method and material. Lesson Study approach which is supported by appreciative learning material will boost the goal to improve students' active participation and their competencies in terms of speaking skill. Lesson Study gives chances for students to be actively participating to create positive atmosphere of learning and teaching, and hence to motivate the learners to construct their own understanding through learning experience directly. Appreciative learning material becomes a starting foreplay to help students to initiate and to state their opinions and minds in spoken language. The result of analysis shows that $93 \%$ of the students can be able to speak fluently on their presentations, interviews, and conversations with respect to some aspects of assesment rubric.
\end{abstract}

Keywords: controlled freedom, high thinking order, motivation

\section{Pendahuluan}

Tujuan pembelajaran bahasa Jepang di Indonesia khususnya di tingkat pendidikan tinggi yaitu Perguruan Tinggi (PT) membentuk kemampaun berkomunikasi dengan bahasa Jepang pada pembelajar. Kemampuan berkomunikasi di sini lebih khusus difokuskan pada ketrampilan berbicarayang ditunjukkan dengan kemampuan melakukan percakapan dengan bahasa Jepang baik dengan sesama pembelajar bahasa Jepang maupun dengan penutur asli bangsa Jepang. Untuk mencapai tujuan tersebut, bukan merupakan 
hal yang mudah, pengajar (dalam hal ini dosen) tentunya telah mencoba dengan berbagai strategi dan pendekatan, tetapi karena membentuk sebuah kompetensi bukanlah hal yang mudah sehingga permasalahan keterampilan berbicara bahasa Jepang pada mahasiswa bahasa Jepang di PT tidak pernah tertuntaskan.

Guna mengatasi permasalahan tersebut peneliti sebagai dosen pengampu mata kuliah JokyuHanashikata (Keterampilan Berbicara Tingkat Mahir) telah mencoba mulai dari aspek materi/bahan ajar. Semula bahan ajar menggunakan buku paket khusus untuk Hanashikatayang ditulis oleh pengarang orang Jepang dan diterbitkan oleh penerbit di Jepang dengan tujuan agar standarisasi bahasa Jepang yang digunakan sudah valid dan terjaga tingkat kebenaran dan keberterimaan bahasanya. Buku ini dilengkapi dengan DVD sehingga mahasiswa selain dapat membaca materi dalam buku teks juga dapat mendengarkan contoh percakapan yang diperankan oleh penutur asli orang Jepang dan dapat melihat sikap dan gerak pemeran. Dengan bahan ajar seperti ini peneliti berharap agar mahasiswa selain belajar keterampilan berbicara juga dapat berlatih keterampilan menyimak yang diasumsikan mahasiswa dapat menirukan suara, logat, sikap dan gerakan sehingga dapat menghasilkan keterampilan berbicara yang lebih baik. Tetapi realitanya, hasil yang peneliti terima tidak begitu menggembirakan dan ternyata belum dapat banyak membantu meningkatkan keterampilan berbahasa mahasiswa karena, mahasiswa lebih cenderung menghafalkan teks percakapan dan kurang dapat memberi kesempatan serta tidak merangsang mahasiswa untuk berfikir berdasarkan pengalaman dan kemampuannya sendiri. Bahan ajar seperti ini membuat ketergantungan mahasiswa terhadap ketersediaan materi yang ada di dalam buku teks. Meskipun segi positifnya bagi mahasiswa yang aktif dapat lebih menyiapkan materi yang belum diajarkan oleh dosen, tetapi ketergantungan mahasiswa terhadap materi yang telah tersedia di dalam buku teks secara tidak disadari telah membunuh kreatifitas mahasiswa. Sehubungan dengan permasalahan tersebut di atas perlu kiranya memberikan sebuah penawaran sebagai solusi guna mengurangi tingkat kompleksitas permasalahan pembelajaran.

Pendekatan pembelajaran dengan memberikan kelonggaran dan kebebasan pembelajar mengembangkan potensi berpikir melalui keterlibatan pengajar dan pembelajar dimungkinkan dapat meningkatkan kualitas pembelajaran. Sejalan dengan pendapat ini Matoba menyebutkan, perbaikan pengajaran dilakukan melalui keterlibatan langsung terhadap peningkatan dan perkembangan kemampuan guru dan siswa (2008:149). Artinya, guna meningkatkan kualitas pembelajaran sebaiknya dilakukan dengan melibatkan kedua belah pihak yaitu pengajar (guru) dan pihak yang belajar (siswa). Peningkatan kualitas guru dapat melalui pengembanganpendekatan, model pembelajaran, dan pengembangan materi, sedangkan peningkatan kualitas peserta didik dapat berupa keterlibatan siswa secara langsung dalam proses pembelajaran seperti siswa diberi kepercayaan dan kebebasan mengembangkan materi melalui topik pembelajaran yang telah ditentukan. Dengan mengembangkan topik pembelajaran secara tidak langsung telah memberikan kesempatan kepada peserta didik menggunakan materi pembelajaran dalam kehidupan nyata. Oleh karena itu, guru sebaiknya juga harus kreatif untuk mengembangkan materi pembelajaran yang memiliki keterkaitan dengan kehidupan nyata. Sehubungan dengan hal ini Matoba (2003:161) juga menyatakan bahwa, hal-hal yang terkait dengan kehidupan nyata, kehidupan sehari-hari dapat digunakan 
sebagai perangsang untuk meningkatkan motivasi anak dalam mengawali aktivitas belajar. Jika hal-hal yang memiliki keterkaitan dengan kehidupan nyata diangkat sebagai bahan materi ajar, berarti guru tidak membawa peserta didik ke dunia "awang-awang" tetapi lebih "membumi"akibatnya peserta didik merasa mengalami sendiri secara langsung. Sebagai akibat peserta didik akan termotivasi dan akan dapat mengkonstruksi pemahamannya melalui pengalaman sendiri bukan karena dari hasil cerita orang lain. Subandi (2008:13) menyebutkan, keberlanjutan pada setiap tahapan proses pelajaran diawali oleh motivasi siswa, dimana siswa dapat melakukan proses pemahaman melalui pengamatan dengan kemampuannya sendiri dan didukung oleh hasil kerjasama di antara siswa itu sendiri. Artinya bahwa, model pembelajaran yang membawa peserta didik ke dunia yang lebih kongkrit dan nyata dapat meningkatkan motivasi mereka dan pada akhirnya dapat mendukung keberlangsungan proses pembelajaran.

Pembelajaran dengan model Lesson Study yang didukung oleh bahan ajar "mentah" yaitu materi ajar yang memanfaatkan fenomena-fenomena yang berkembang di masyarat adalah solusi yang ditawarkan. Lesson Study dianggap mampu memberikan peran maksimal terhadap keterlibatan peserta didik dalam proses pembelajaran. Peserta didik dalam model ini berperan sebagai pelaku utama yang berpotensi mengembangkan konsep sebuah topik pembelajaran, sedangkan guru sebagai nara sumber yaitu tempat peserta didik mengonfirmasikan pendapat siswa dan guru sebagai mediator yang mempertemukan berbagai ide dari para peserta didik untuk dijadikan satu kesatuan pengetahuan yang utuh. Kelonggaran dan kewenangan peserta didik mengembangkan dan mengaktualisasikan ide dan pikirannya akan lebih lengkap jika didukung dengan bentuk materi pembelajaran yang dapat merangsang pembelajar untuk menggali pengetahuan berdasarkan pengalamannya yang diperoleh dalam kehidupan nyata. Hal ini didukung oleh pendapat Sanjaya (2006:226) yang menyebutkan bahwa, model pembelajaran yang bertumpu kepada pengembangan kemampuan berpikir peserta didik melalui telaah fakta-fakta atau pengalaman peserta didik sebagai bahan untuk memecahkan masalah yang diajukan. Dengan demikian memberikan pengertian bahwa pembelajaran merupakan peristiwa mental yang diwujudkan dalam bentuk kegiatan yang melibatkan aspek kognitif peserta didik secara individu guna membangun pengetahuan. Materi ajar yang dihubungkan dengan realita kehidupan nyata diyakini dapat membawa peserta didik ke dunia yang lebih kongkrit sehingga akan dapat membantu mempermudah peserta didik terhadap pengkonstruksian pengetahuan dan pemahamannya.

\section{Lesson Study}

Lesson Study pertama kali muncul di Jepang yang disebut dengan istilah Jugyou Kenkyuu. Lesson Study memiliki karakteristik kolaboratif yang melibatkan pihak lain sebagai mitra. Seperti disampaikan oleh Inagaki dan Satou bahwa Lesson Study melibatkan beberapa komponen antara lain peneliti, guru, dan pengamat yang semuanya harus mengesampingkan suatu perbedaan antara peneliti dan pelaksana pengajaran yaitu guru yang diharapkan munculnya pengembangan aspek teoritis dan aplikasi yang searah (1996:3). Komponen yang terlibat dalam Lesson Study harus mampu bekerjasama dalam rangka mencapai tujuan pembelajaran yaitu perbaikan kualitas proses pembelajaran dengan harapan jika terjadi perbaikan kualitas proses maka akan berakibat pada meningkatnya kualitas hasil pembelajaran. Seperti yang telah disampaikan oleh Fernandezbahwa Lesson 
Study yang telah dilakukan di Jepang sampai saat ini telah menghasilkan banyak kelompok atau perhimpunan yang memiliki komitment terhadap peningkatan kualitas pendidikan melalui Lesson Study(2002:394). Oleh karena itu peningkatan kompetensi guru, perbaikan pengajaran, pengalaman serta perkembangan peserta didik, masingmasing merupakan unsur penting yang memiliki hubungan yang sangat erat (Subandi, 2008:135). Artinya, bahwa komponen-komponen yang terlibat di dalam Lesson Study tidak dapat berdiri sendiri-sendiri dan terpisah, semuanya harus bersinergis membentuk satu kekuatan dengan mendasari konsep kolaboratif guna mencapai satu tujuan yaitu perbaikan. Dengan karakteristik seperti ini maka Lesson Study dapat difungsikan sebagai sarana refleksi, komunikasi, dan bertukar pengalaman bagi pengajar dengan mitra yang terlibat guna meningkatkan perbaikan kompetensi guru, perbaikan proses pengajaran, dan pembelajaran aplikatif. Selain itu bagi siswa dengan model pendekatan seperti ini memungkinkan peserta didik akan merasa ringan dan tidak terbebani karena memiliki kebebasan berimprovisasi maupun bebas menyampaikan ide dan pikiran.

Lesson Study tidak hanya berdampak pada pengajar tetapi juga dapat memberikan dampak positif terhadap peserta didik. Hal ini dikarenakan keterlibatan peserta didik di dalam proses pembelajaran mendapat prioritas utama dan sangat dioptimalkan. Keberlangsungan pembelajaran terletak pada peserta didik, sedangkan guru hanya berperan sebagai pengendali dan mengatur jalannya lalulintas proses pembelajaran. Dengan peran dan tugas seperti ini mengharuskan peserta didik harus berperan aktif agar lalulintas pembelajaran tidak berhenti. Dengan demikian secara tidak disadari, Lesson Srudy dapat membentuk jiwa kreatif dan aktif pada peserta didik. Peserta didik dilatih untuk mencari dan menemukan sendiri konstruksi pemahaman melalui pengamatan, pengalaman, dan penemuan berdasarkan tingkat kemampuan dan pengetahuan masing-masing. Hasil dari pengamatan, pengalaman, dan penemuan tersebut selanjutnya dikonfirmasikan dengan antar anggota kelompok melalui kerja kelompok, maupun melalui diskusi antar kelompok. Dengan demikian, selain peserta didik dibentuk jiwa kemandiriannya juga jiwa dan semangat kerja sama terbentuk melalui Lesson Study.

Proses pembelajaran dengan menggunakan model Lesson Study sejatinya sangat membantu peningkatan kualitas pembelajaran bagi guru dan peserta didik. Dengan karakteristik kolaboratif, guru memiliki kesempatan untuk melakukan perbaikan melalui tukar pikiran baik sesama guru dalam tim, dengan para pengamat maupun dengan para ahli yang terlibat dalam Lesson Study. Pendapat masingmasing guru didiskusikan dalam tahap refleksi sehingga dari berbagai pendapat dan masuk dapat diakomodir dan digunakan untuk menyempurnakan pendapat pribadi guru maupun pendapat kelompoknya. Shin menyebutkan bahwa, ada dua informasi penting yang perlu diperhatikan saat melaksanakan Lesson Study yaitu, pertama, informasi yang diperlukan untuk menyelesaikan permasalahan, yaitu untuk memahami permasalahan informasi yang berfungsi sebagai proses dan kedua, informasi yang digunakan untuk mengarahkan pemahaman terhadap konsep dasar permasalahan, yaitu untuk menemukan jawaban terhadap konsep informasi (1996:17). Artinya, kedua informasi tersebut perlu dimiliki oleh guru karena, guru harus mampu memahami konsep informasi dan harus mampu meyampaikan kepada peserta didik. Jika guru hanya mampu memahami informasi tetapi tidak mampu menyampaikan kepada peserta didik, maka berarti guru tidak 
mampu mengelola konsep informasi tersebut.

\section{Materi Ajar}

Materi ajar merupakan salah satu komponen terpenting dalam pelaksanaan prose belajar mengajar. Materi ajar turut menentukan tercapai atau tidaknya tujuan pembelajaran. Ketepatan pemilihan dan penggunaan materi ajar akan dapat menbentuk atmosfir belajar mengajar yang lebih nyaman dimana kondisi seperti ini akan sangat mendukung ketercapaian tujuan pembelajaran. Hal ini sejalan dengan pendapat Cunningzworth yang menyebutkan bahwa tidak ada sesuatu yang mampu mempengaruhi suasana mengajar dan belajar lebih dari bahan ajar (dalam Sumardi, 2001:4). Artinya bahwa, materi ajar memiliki peranan kunci dalam proses pembelajaran karena ketepatan penggunaan materi ajar juga memberikan kontribusi terhadap terbentuknya suasana pembelajaran yang konduksif. Sehubungan dengan hal tersebut karena tujuan pembelajaran yang menjadi kajian penelitian ini adalah mata kuliah Percakapan Tingkat Mahir(Jokyu Hanashikata) dimana lebih menekankan pada pembentukan kompetensi keterampilan berbicara maka, materi ajar harus benar-benar dapat memberi peluang dan kesempatan kepada peserta didik untuk menggali dan mengembangkan kompetensi berbicaranya. Materi ajar harus lebih apresiatif dan menekankan pada aspek keterlibatan langsung peserta didik dan harus menghindari materi ajar yang bersifat teoritis akademis yang hanya menekankan pada aspek pengetahuan. Materi ajar yang hanya mengutamakan aspek pengetahuan cenderung akan membawa peserta didik ke posisi yang lebih apstrak dan justru akan menjadi beban bagi peserta didik. Sodiq menyebutkan bahwa pembelajaran yang menekankan pada pengetahuan, secara kejiwaan akan cenderung menjadi beban bagi siswa (dalam Yuwana, 2007:60). Oleh sebab itu materi ajar yang memiliki kecenderungan membawa peserta didik ke arah pembelajaran pengetahuan sebaiknya dihindari dan lebih memilih materi ajar yang membawa peserta didik ke arah apresiatif.

Materi ajar yang bersifat apresiatif akan dapat membentuk karakter dan jiwa peserta didik untuk lebih berani menyampaikan pikiran dan gagas karena, materi ajar yang apresiatif lebih memberikan kesempatan dan dorongan kepada peserta didik untuk mengembangkan pikiran dan gagasan melalui informasi awal yang tertuang di dalam kerangka draf materi.Seingga pembelajaran lebih bermakna karena materi dapat dihubungkan dengan realita yang ada di dalam kehidupan riel dalam masyarakat. Seperti yang disampaikan oleh Brown yang menyebutkan bahwa, pembelajaran bermakna sebagai proses menghubungkan dan menggabungkan materi baru pada halhal yang ada dalam struktur kognitif yang selanjutnya materi baru tersebut akan berinteraksi dan digabungkan secara semestinya ke dalam sebuah sistem konseptual yang lebih luas (2007:98). Peserta didik diberi kerangka draf materi yang hanya berisi tema, kata kunci, daftar pertanyaan, dan kolom pendapat dan atau alasan. Tema dipilihkan fenomena yang sedang terjadi di dalam kehidupan masyarakat umum dan atau permasalahan yang mungkin akan terjadi di dalam kehidupan nyata. Dengan demikian, peserta didik tidak dituntut memiliki pengetahuan tertentu secara mendalam tetapi lebih menitik beratkan pada aspek keterlibatan dan atau pengalaman kehidupan peserta didik baik pengalaman yang telah dialami maupun fenomena yang akan terjadi yang akan membentuk pengalaman baru bagi peserta didik. Dengan kerangka materi seperti ini maka peserta didik diberi kesempatan dan didorong untuk 
mengembangkan logika berpikirnya dengan memanfaatkan pengalaman dan hasil pengamatan terhadap realita kehidupan sebagai bahan pengembangnya.Dalam pembelajaran keterampilan berbicara mahir ini ditetapkan 8 tema diantaranya, "Baju Seragam", "Studi sambil Kerja", "Pembangunan Daerah Wisata di Pedesaan", "Dipilihkan Orang Tua atau Pilihan Sendiri?", "Internet dan Kehidupan", "Mendidik Anak dengan Berbagai Kursus", "Ibu Rumah Tangga dan Istri Karier", dan "Buah Import dan Buah Lokal". Dengan karakter materi ajar seperti ini diharapkan dapat mengurangi jiwa ketergantungan terhadap ketersediaan materi secara utuh dari buku teks, dapat mengurangi kejenuhan peserta didik, dan dapat membuat suasana belajar menjadi lebih menyenangkan. Jika kejenuhan suasana belajar dapat digantikan oleh kesenangan akibat ketepatan pemilihan dan penggunaan materi ajar maka, suasana proses belajar akan menjadi hidup dan sehat yang pada akhirnya akan dapat membantu mempercepat ketercapaian tujuan pembelajaran. Seperti yang disampaikan oleh Ornstein bahwa, kesenangan dalam belajar sangat penting (1985:120).Artinya, suasana yang menyenangkan sangat dibutuhkan dalam kegiatan pembelajaran terutama bagi peserta didik dan suasana menyenangkan ini salah satunya harus dapat ditemukan dalam kemasan materi ajar. Dengan suasana materi seperti ini akan mampu membawa peserta didik memasuki tahap kemandirian terhadap potensi dirinya, serta mereka tidak meras tersiksa yang diakibatkan karena merasa kesulitan dan dapat menemukan suatu kesimpulan yang ingin dicapai pada akhir kegiatan pembelajaran (lihat pula James W. Stigler, 1996:237).

\section{Metode Penelitian}

Peneliti mengaplikasikan konsep Lesson Study yang didukung dengan materi ajar mentah untuk pembelajaran keterampilan berbicara tingkat mahir mahasiswa Prodi Pendidikan Bahasa Jepang Fakultas Bahasa dan Seni (FBS) Universitas Negeri Surabaya (Unesa) tahun akademik 2008/2009. Mahasiswa angkatan tahun 2008 berjumlah 73 mahasiswa terdiri dari dua kelas yaitu kelas A berjumlah 37 mahasiswa dan kelas B berjumlah 36 mahasiswa. Secara umum, kemampuan keterampilan berbicara bahasa Jepang mahasiswa Prodi Pendidikan Bahasa Jepang FBS Unesa tergolong rendah. Oleh sebab itu, peneliti mengaplikasikan konsep model Lesson Study yang didukung oleh materi ajar yang terkait dengan realita hidup di masyarakat, diharapkan dapat menjadi solusi guna meningkatkan kompetensi keterampilan berbicara mahasiswa. Penelitian ini dilaksanakan selama satu semester dengan total pertemuan 14 kali tatap muka. Dalam pelaksanaan penelitian ini, peneliti dibantu oleh satu dosen muda lokal dan satu dosen muda native speacker serta dibantu dua mahasiswa untuk membantu pengambilan rekaman video/handycam.

Sebelum pelaksanaan dilakukan persiapan mulai dari mempersiapkan perangkat pembelajaran dan instrumen penelitian. RPP yang digunakan adalah model RPP yang dikembangkan oleh The Japan Foundation, karena dianggap lebih sederhana, menyeluruh, dan praktis. Setelah persiapan sudah dianggap cukup, masuk tahap pelaksanaan. Selama pelaksanaan PBM peneliti berperan sebagai pengamat dibantu oleh salah satu dosen muda yang tidak bertugas mengajar. Setiap kali pelaksanaan PBM berakhir langsung diadakan refleksi guna mengevaluasi pelaksanaan PBM. Aspek-aspek yang telah terlaksana dengan baik didata untuk dipertahankan dan ditingkatkan sedangkan aspek yang belum terlaksana dengan baik dicatat untuk digunakan sebagai bahan diskusi guna dicarikan solusinya. Diskusi lebih difokuskan pada aspek-aspek yang 
belum tercapai untuk diadakan perbaikan agar pada tatap muka PBM berikutnya tidak terjadi dan kualitas PBM menjadi lebih baik.

\section{Hasil dan Pembahasan}

\section{Persiapan}

Sebelum proses belajar mengajar dimulai seperti biasa dilakukan persiapan. Pada tahap persiapan ini yang dilakukan meliputi penyusunan Rencana Program Pengajaran (RPP). RPP disusun secara bersama dengan tim yang terdiri dari 3 orang yaitu peneliti, satu dosen muda native speacker dan satu dosen muda lokal. Setelah dapat masukan dari validator yaitu dosen senior native speacker kemudian RPP direvisi berdasarkan masukan tersebut yang menghasilkan RPP revisi. Revisi RPP terdiri dari perbaikan urutan penggunaan ungkapan yang ditujukan untuk menolak pendapat orang lain dan ungkapan untuk mengungkapkan pendapat pribadi. Masukan dari validator bahwa penggunaan ungkapan-ungkapan tersebut agar dihubungkan dengan konteks sosial budaya masyarakat Jepang. Secara keseluruhan RPP sudah bagus dan jelas, KD, Tujuan Pembelajaran, Indikator ketercapaian, penilaian sudah mampu memberikan gambaran yang jelas, runtut dan memiliki keterkaitan antara materi yang satu dengan lainnya.

Selanjutnya setelah RPP sudah siap, persiapan penyusunan materi ajar mulai dari kerangka sistematika, urutan materi, penggunaan huruf kanji pada materi, serta bentuk ungkapan yang mungkin muncul dan memiliki keterkaitan dengan tema materi. Materi yang telah tersusun dimintakan masukan kepada validator. Terkait materi ini validator memberi masukan terkait pembetulan kaidah penulisan huruf katana. Setelah materi direvisi sesuai dengan masukan dari validator selanjutnya peneliti menyiapkan lembar kegiatan.

Lembar kegiatan ini diberikan agar mahasiswa dapat mengembangkan logika berfikir dengan memanfaatkan pegalaman dan informasi yang sudah pernah diperoleh di dalam kehidupan sehari-hari guna memaksimalkan kemampuan berpikir mahasiswa. Dengan lembar kegiatan ini materi tersaji secara garis besar saja yang sekaligus berfungsi sebagai stimulus dengan dilengkapi beberapa pertanyaan untuk membantu mahasiswa agar lebih mudah mengawali mengungkapkan ide dan pikirnnya. Jenis pertanyaan yang diberikan adalah pertanyaan terbuka yang memberikan kelonggaran dan kebebasan kepada mahasiswa untuk menuangkan semua ide dan pikiran tanpa ada intervensi dari teman maupun dosen. Berdasarkan jawaban atas pertanyaan tersebut mahasiswa diminta untuk memberikan alasan mengapa meraka menjawab seperti itu, alasan yang mendasari jawaban tersebut, bagaimana sikap mahasiswa terhadap jawaban yang tidak sama dengan jawaban mereka dan sebagainya. Secara garis besar format penyajian materi dalam lembar kerja adalah sebagai berikut. 
1. テーマ: 制服

《活動 1 》グループディスカッション

2. キーワード

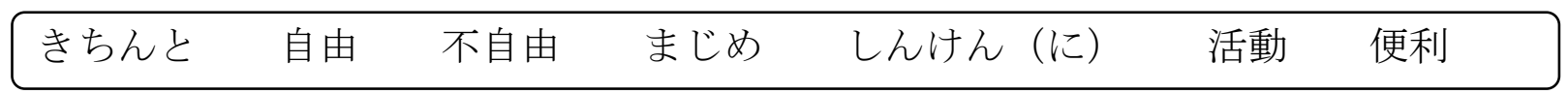

3. 問題

Q1. 制服についてどう考えますか：

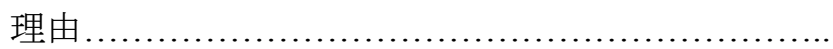

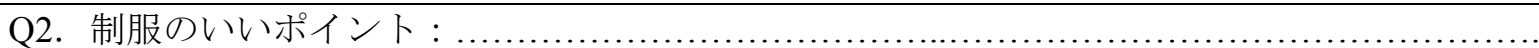

理由.

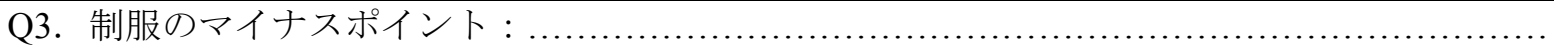

理由

Pada no 1 tema materi pada pertemuan tersebut dan bentuk kegiatan seperti diskusi kelompok yaitu mendiskusikan tentang tema "Seragam". No 2 diberikan kata kunci untuk membantu mahasiswa merangsang memunculkan ide dan kemungkinan menghubungkan dengan hal-hal yang berhubungan dengan kata kunci. Dan no 3 contoh pertanyaan untuk memancing mahasiswa agar dengan bantuan pertanyaan mahasiswa dapat mengawali menyusun jawaban dan jawaban yang diberikan harus disertai alasan (terkait fungsi pemancingan pengalaman, lihat juga Hudson, 2007:39). Bentuk jawaban diklasifikasikan menjadi dua karakter yaitu jawaban setuju atau tidak setuju dan jawaban uraian yang diklasifikasi aspek positif dan aspek negatifnya. Jika mahasiswa menjawab setuju, mengapa setuju dan apa alasannya sebaliknya jika mahasiswa tidak setuju mengapa setuju dan apa alasannya, begitu seterusnya.

Guna mendukung ketercapaian tujuan pembelajaran perlu disediakan instrumen pembelajaran. Instrumen yang perlu dibahas di sini adalah keterlaksanaan pembelajaran yaitu lembar observasi yang digunakan untuk mengamati saat berlangsung proses belajar mengajar dan instrumen penilaian yang berupa angket guna mengetahui efektivitas model pembelajaran dan model materi serta untuk mengetahui keberterimaan model pembelajaran dan model materi oleh mahasiswa. Angket dibuat dengan dua tipe dalam satu format yaitu angket yang terdiri dari pertanyaan dengan tipe jawaban tertutup dan angket terbuka yang terdiri dari pertanyaan dengan tipe jawaban uraian. Secara keseluruhan pengadaan angket bertujuan untuk mendapatkan masukan dan respon dari peserta didik terkait dengan proses belajar mengajar. Pertanyaan uraian ditujukan untuk memperoleh informasi dari mahasiswa terkait kebutuhan, keingin, dan masukan dari mahasiswa terkait model, materi, ketercapaian tujuan pembelajaran, dan tema materi. Pengadaan lembar observasi ditujukan untuk mengetahui keterlaksanaan rencana pengajaran, keaktifan peserta didik, ketuntasan pembelajaran, dan ketercapaian tujuan pembelajaran.

\section{Pelaksanaan}

a. Pembukaan

Informasi pelaksanaan ini diperoleh dari hasil observasi dengan menggunakan instrumen lembar observasi yang dilakukan oleh anggota tim. Awal pelaksanaan kegiatan pembelajaran pengajar telah memulai dengan tahap pembukaan yaitu dimulai dengan salam dan memastikan 
bahwa mahasiswa telah hadir semua yang dicek dengan pelaksanaan absensi. Setelah diketahui semua mahasiswa sudah hadir pengajar melanjutkan dengan memastikan kesiapan mahasiswa untuk mengikuti proses pembelajaran dan dilanjutkan dengan menjelaskan tema materi pembelajaran serta tujuan pembelajaran. Selanjutkan diikuti dengan proses pemancingan yaitu, pengajar memberikan pertanyaan kepada beberapa mahasiswa terkait dengan pernah menggunakan baju seragam, kapan menggunakan baju seragam, senang tidak menggunakan baju seragam, bagaimana rasanya saat menggunakan baju seragam, kangen tidak dengan suasana baju seragam dan sejenisnya. Pengajar juga memberikan kesempatan secara bebas bagi mahasiswa yang ingin menjawab tanpa menunggu ditunjuk jika mungkin ada jawaban lain dan berbeda dengan jawaban yang telah dijawab oleh temannya yang telah ditunjuk oleh pengajar. Setelah dipastikan tidak ada mahasiswa yang akan memberikan jawaban lagi pengajar menyuruh mahasiswa untuk membentuk kelompok dengan jumlah anggota setiap kelompok 4 orang mahasiswa lalu mengajak mendiskusikan dengan temanteman satu kelompok tentang "baju seragam" (terkait kerja kelompok lihat pula Gagne, 1979:242).Pembentukan kelompok dapat berjalan dengan baik dan cepat kurang dari waktu yang telah diberikan tanpa ada interfensi dosen. Nampaknya mahasiswa masih menerapkan kebiasaan pembetukan kelompok yang telah dilaksanakan ketika mereka mengikuti mata kuliah Keterampilan Berbicara III yang diampu oleh dosen yang sama. Secara keseluruhan tahap pembukaan yang dilakukan oleh pengajar sudah sangat baik dan jelas khususnya saat menjelaskan materi yang akan dipelajari, tujuan pembelajaran, dan teknik pemancingan guna mempersiapkan peserta didik agar benar-benar siap mengikuti pembelajaran.
Tahap pembukaan ini dilanjutkan dengan tahap inti yang ditandai dengan dimulainya kerja kelompok.

\section{b. Kegiatan Inti}

Dosen memastikan kesiapan kelompok-kelompok dengan mendatangi dan mengecek setiap kelompok sebelum memberikan instruksi terkait pembelajaran. Setelah dirasakan siap, dosen membagikan lembar kegiatan mahasiswa kepada semua mahasiswa dan dilanjutkan pemberian instruksi tentang hal-hal yang harus dikerjakan selama kerja kelompok. Pertama dosen menginstruksikan agar semua membaca informasi yang ada di lembar kegiatan mahasiswa, setelah itu dosen menyuruh agar permasalahan yang ada didiskusikan dengan anggota kelompok dan hasilnya dicatat selanjutnya dilaporkan dan didiskusikan bersama dengan kelompok yang lain. Dosen memberikan waktu untuk kerja selama 20 menit termasuk mencatat hasil kerja kelompok.Dosen menyampaikan instruksi secara jelas meskipun instruksi disampaikan dengan bahasa Jepang, tetapi karena bahasa Jepang dan pemilihan katanya juga yang mudah dipahami sehingga semua mahasiswa nampak sekali dapat memahami kegiatan yang akan dilakukan. Pada kegiatan inti ini secara keseluruhan dibagi menjadi tiga kegiatan yaitu, kegiatan kerja kelompok, kegiatan pelaporan, dan kegiatan debat diskusi.

Selama kegiatan kerja kelompok berlangsung, dosen bersama tim teaching yang lain yang bertugas mengobservasi mengontrol dengan cara berkeliling dari kelompok yang satu ke kelompok lainnya. Sesekali para dosen yang terlibat dalam satu tim memberikan masukan dan atau pengarahan kepada beberapa mahasiswa yang dirasa perlu diberi bantuan. Secara keseluruhan, sebagian besar mahasiswa sudah dapt menjalankan tugasnya masingmasing, yaitu saling bertukar pendapat dengan teman sesama kelompok. Memang 
masih ada beberapa mahasiswa yang belum dapat mengikuti kegiatan secara aktip dan masih lebih banyak mendengarkan saja tanpa diikuti pemberian ide dan pendapat terkait topik permasalahan yang sedang didiskusikan. Sehubungan dengan kondisi seperti ini dosen memberikan perhatian secara khususuntuk memberi bimbingan agar anggota yang pasip juga diberi kesempatan untuk terlibat memikirkan dan memecahkan permasalahan yang sedang didiskusikan. Selanjutnya mahasiswa seperti tersebut juga harus diberi kesempatan untuk menyampaikan pendapatnya agar mereka mendapatkan kesempatan yang sama dengan teman anggota yang lain. Nampaknya bukan hal yang mudah untuk membentuk karakter mahasiswa aktif karena, meskipun sudah diberi bimbingan dan masukkan oleh dosen baik dosen pengajar maupun dosen yang bertugas mengamati tidak serta merta mahasiswa yang pasif berubah menjadi aktif. Namun demikian meskipun tidak seaktif teman anggota yang lain nampak ada perubahan, di antara mahasiswa tersebut sudah mulai ada yang mau bertanya kepada teman anggotanya dan membantu menuliskan hasil diskusi. Tetapi masih belum mau memberikan pendapat karena dari sikapnya masih kelihatan sekali ragu dan gugup ketika menyampaikan pertanyaan meskipun kepada sesama teman. Terkait dengan hal ini dosen terus memberikan dorongan serta meyakinkan mereka agar tidak ragu atau malu untuk menyampaikan semua gagasan yang ada di dalam pikiran mereka dan didorong terus agar tidak takut salah. Semua dosen yang terlibat dalam tim nampak sekali pro-aktif guna membentuk karakter mahasiswa aktif dan untuk mengembangkan dan memaksimalkan potensi berfikir mahasiswa. Hal ini nampak sekali ketika para tim memberikan dorongan terutama kepada mahasiswa yang pasif. Para tim dengan penuh ketelatenan membimbing mereka dan memancing dengan beberapa pertanyaan sampai mereka mau bertanya.

Waktu 20 menit yang diberikan oleh dosen untuk bekerja kelompok telah habis. Selanjutnya ketika dosen mengkonfirmasikan kepada semua kelompok tentang sudah selesai atau belum kerja kelompoknya, ternya masih ada dua dari sembilan kelompok yang belum selesai. Setelah dosen menanyakan kesulitan yang dihadipi oleh kedua kelompok tersebut, ternyata permasalahan yang dihadpi oleh kedua kelompok tersebut sama yaitu kesulitan menemukan kosa kata yang tepat guna merealisasikan ide dan pikiran mereka. Setelah kedua kelompok ini secara bergantian diminta oleh dosen untuk menyampaikan gagasan mereka dengan menggunakan bahasa Indonesia, sangat kelihatan bahwa gagasan yang ingin disampaikan memang sangat bagus dan memiliki tingkat berpikir tinggi. Sehingga sangat wajar jika mereka memiliki keterbatasan untuk mendapatkan kosa kata yang tepat yang benar-benar bisa mewakili pikirannya. Akhirnya dosen membantu memberikan kosa kata yang diperlukan oleh kedua kelompok tersebut dan diberi waktu untuk segera menyelesaikan pekerjaannya. Konskuensinya waktu kerja kelompok menjadi molor sekitar tujuh menit. Setelah mendapat kepastian bahwa semua kelompok telah menyelesaikan tugasnya, dosen segera mengajak peserta didik untuk mempersiapkan kegiatan berikutnya yaitu pelaporan hasil dan diskusi antar kelompok.

Memasuki tahap pelaporan hasil dan diskusi antar kelompok, dosen mengawali dengan memberikan instruksi, agar ketika salah satu kelompok melaporkan kelompok yang lain mencatat informasi yang disampaikan. Selanjutnya dosen tidak menunjuk kelompok mana yang harus tampil terlebih dahulu, tetapi dosen langsung membuka kesempatan kepada semua kelompok yang sudah siap tampil terlebih dahulu. Setelah dosen membuka 
kesempatan, semua perwakilan dari masing-masing kelompok langsung mengangkat tangan sebagai tanda kelompoknya siap untuk melakukan tahap pelaporan hasil. Karena semua kelompok menyatakan siap, maka dosen menunjuk secara acak dan berurutan. Saat salah satu kelompok melakukan pelaporankelompok yang lain mengikuti sambil mencatat isi pelaporan.

Setelah masuk tahap pelaporan dan diskusi sampai pada tiga kelompok, dari ketiga kelompok yang telah melakukan pelaporan, semua kelompok hanya didominasi oleh satu orang yaitusalah satu anggota khusunya yang ditetapkan sebagai juru bicara. Sedangkan anggota kelompok yang lain hanya mengikuti dan mendengarkan saja. Kondisi ini sangat tidak sesuai dengan tujuan pembelajaran, yaitu memberikan kesempatan yang sama kepada semua peserta didik guna meningkatkan kompetensi khususnya kompetensi berbicara mereka. Karena pelaporan hanya diwakili oleh satu mahasiswa yang menjadi juru bicara, maka kesempatan untuk melatih keterampilan berbicara mereka hanya peroleh dan dirasakan oleh satu mahasiswa yaitu yang melakukan pelaporan saja, sedangkan anggota yang lain karena hanya mendengarkan saja maka mereka tidak mendapatkan kesempatan berlatih berbicara. Akhirnya agar kondisi tidak berlanjut dosen mengambil inisiatifmenghentikan tahap pelaporan sekitar tiga menit guna memberikan pengarahan dan bimbingan. Dosen menyarankan agar pelaporan tidak hanya dilakukan oleh satu anggota saja tetapi harus dibagi secara merata dengan anggota yang lain agar setiap anggota memiliki kesempatan dan pengalaman yang sama. Setelah pengarahan selesai dosen kembali membuka kesempatan kepada kelompok untuk melanjutkan proses pelaporan. Ternyata hanya satu kelompok yang menyatakan siap, sedangkan kelompok yang lain belum mengangkat tangan seperti pada awal tahap pelaporan. Nampaknya kondisi ini sebagai akibat dari pengarahan dosen yang menyarankan agar pelaporan dilakukan oleh setiap anggota kelompok, dan masing-masing kelompokkelompok nampaknya masih sedang membagi tugas kepada masing-masing anggotanya. Akhirnya dosen memberikan kesempatan kepada kelompok yang telah siap.

Nampaknya kelompok yang sudah siap ini telah membagi tugas dengan anggotanya karena saat pelaporan hasil berjelan antar anggota sudah dapat menjalankan tugas masing-masing secara bergantian dan berurutan serta tidak nampak terjadinya pembagian tugas saat proses pelaporan berlangsung. Sehingga proses pelaporan oleh kelompok ini nampak lebih lancar, suasana lebih hidup dan bervariasi karena terjadi proses pergantian peserta yang melakukan pelaporan. Yang lebih bagus lagi kelompok ini juga telah membagi tugas anggota yang bertugas membuka dan anggota yang bertugas menutup pelaporan sekaligus membuka sesi diskusi dan tanya jawab dilakukan oleh dua anggota yang berbeda. Hal ini berbeda dengan tiga kelompok yang tampil sebelumnya, pada tiga kelompok sebelumnya membuka, isi, dan menutup dilakukan oleh anggota yang sama sehingga tidak nampak terjadi pergantian suasan. Setelah kelompok yang tampil diurutan keempat ini, kelompok selanjutnya melakukan pembagian tugas dengan anggota-anggotanya kurang lebih sama. Hanya ada beberapa kelompok yang membagi tugas membuka dan menutup oleh satu anggota saja tetapi meskipun begitu, karena pada saat pelaporan isi sudah terjadi pergantian anggota yang bertugas sehingga kesan monoton tidak sampai terasa.

Kelompok yang telah selesai melakukan pelaporan hasil dilanjutkan dengan tahap diskusi dan tanya jawab antar kelompok. Memasuki tahap awal tanya 
jawab dan diskusi, hampir semua mahasiswa baik mahasiswa anggota kelompok yang presentasi maupun mahasiswa anggota kelompok lain berperan secara aktif. Setelah memasuki tahap pemberian jawaban oleh kelompok yang presentasi, khususnya pada saat mahasiswa yang tidak presentasi mengkonfirmasikan tanggapan yang disampaikan oleh kelopok yang presentasi mulai nampak tingkat penguasaan dan kemampuan mereka menyampaikan gagasan atau pikiran mereka dengan bahasa Jepang. Saat mereka pertama memberi tanggapan nampak lancar sekali, diperkirakan mereka mempersiapkan saat tenggang waktu mempersiapkan jawaban. Tetapi ketika ada mahasiswa lain meminta penjelasan lebih lanjut rata-rata mereka mengalami kesulitan untuk menemukan ungkapan yang tepat. Dalam kondisi seperti itu, mereka langsung meminta bantuan kepada teman sesama anggota kelompok. Meskipun hal ini sedikit menyita waktu tetapi jika dilihat dari sisi keberlangsungan interaksi sesama anggota, para mahasiswa sudah dapat melaksanakan kerjasama guna mendapatkan pemahaman melalui upaya sendiri maupun melalui kerja sama dengan teman satu kelompoknya. Interaksi semacam ini dianggap mampu memberikan penguatan terhadap pemahaman bagi sesama teman khususnya dalam satu kelompok. Sebagian besar ketika salah satu dari anggotanya mengalami kesulitan untuk memberikan penjelasan, anggota lain yang merasa lebih siap dan memiliki kemampuan berbicara lebih bagus, turut membantu memberikan penjelasan tambahan dengan tujuan agar jawaban yang telah diberikan oleh temannya menjadi lebih jelas.Sebaliknya mahasiswa yang bertanya rata-rata dapat menyampaikan dengan baik dan lancar meskipun kadang kala sambil melihat catatan yang dipegang. Hal ini mengindikasikan bahwa mahasiswa yang bertanya sebelum menyampaikan pertanyaannya terlebih dahulu mereka mengonsep di kertas buram atau buku catatan. Hal ini dibuktikan ketika mereka menyampaikan pertanyaan, kadang-kadang diikuti dengan melihat catatan. Meskipun demikian paling tidak mahasiswa telah mendapatkan kesempatan menemukan pengetahuan dan informasi melalui upayanya sendiri bukan diberi oleh dosen. Pemahaman yang diperoleh oleh mahasiswa dikonstruksi sendiri melalui interaksi dengan teman. Artinya mahasiswa sudah mampu mengkonstruksi pemahamannya sendiri meskipun mendapat bantuan dari teman bukan dibentuk oleh dosen. Secara keseluruhan tahap diskusi dan pembahasan ini berjalan dengan cukup baik dan cukup lancar, hambatan kecil memang juga muncul khususnya, terkait pemilihan bentuk ungkapan atau kosa kata dan istilah tertentu khususnya istilah yang berhubungan dengan bidang keahlian khusus.

\section{c. Penutup}

Masuk tahap penutup, dosen sebelum menutup kegiatan pembelajaran, mengajak semua mahasiswa untuk merangkum garis besar pembelajaran yang telah dilakukan. Rakuman dimulai dari aspek positif pemakaian seragam lalu dilanjutkan dengan aspek negatifnya, serta diikuti oleh kegunaan baju seragam. Setelah merangkum, mahasiswa diminta untuk menyimpulkan dengan mendasari hasil rangkuman guna memperoleh simpulan perlu tidaknya baju seragam.

\section{Hasil Angket}

Berikutnya hasil yang diperoleh dari instrumen angket peserta didik. Secara garis besar isi angket dibagi menjadi dua yaitu, pertanyaan untuk menggali informasi terkait penerapan model Lesson Studyyaitu pertanyaan nomor 1-5 dan pertanyaan yang bertujuan untuk menggali informasi tentang tema/isi dan model format materi ajar yaitu pertanyaan nomor 6-10. Berdasarkan 
instrumen angket respon mahasiswa diperoleh hasil seperti pada tabel berikut.

Tabel Angket Respon Mahasiswa

\begin{tabular}{|c|l|c|c|}
\hline No & \multicolumn{1}{|c|}{ Pertanyaan } & Ya & Tidak \\
\hline 1 & $\begin{array}{l}\text { Apakah menurut Anda model pendekatanLesson Studysesuai untuk mata kuliah } \\
\text { ini? }\end{array}$ & $99 \%$ & 0 \\
\hline 2 & Apakah menurut Anda LessonStudy dapat mengaktifkan peserta didik? & $100 \%$ & 0 \\
\hline 3 & $\begin{array}{l}\text { Apakah menurut Anda Lesson Study dapat memberikan kesempatan terhadap } \\
\text { peserta didik untuk menemukan pengetahuan dan pemahaman dengan mengalami } \\
\text { sendiri? }\end{array}$ & $93 \%$ & $3 \%$ \\
\hline 4 & $\begin{array}{l}\text { Apakah menurut Anda Lesson Study dapat memberikan kebebasan untuk } \\
\text { menyampaikan gagasan dan pikiran peserta didik? }\end{array}$ & $96 \%$ & $1 \%$ \\
\hline 5 & $\begin{array}{l}\text { Apakah menurut Anda Lesson Study dapat membentuk karakter kemandirian dan } \\
\text { kerjasama peserta didik? }\end{array}$ & $98 \%$ & 0 \\
\hline 6 & Apakah tema/isi materi relevan dengan realita kehidupan? & $100 \%$ & 0 \\
\hline 7 & $\begin{array}{l}\text { Apakah materi yang diberikan mampu merangsang berpikir peserta didik untuk } \\
\text { menghubungkan dengan pengalaman dan atau realita hidup? }\end{array}$ & $97 \%$ & $2 \%$ \\
\hline 8 & $\begin{array}{l}\text { Apakah materi yang diberikan mampu merangsang berpikir maksimal terhadap } \\
\text { peserta didik? }\end{array}$ & $87 \%$ & $1 \%$ \\
\hline 9 & Apakah model dan format materi mudah diikuti oleh peserta didik? & $94 \%$ & $4 \%$ \\
\hline 10 & $\begin{array}{l}\text { Apakah model format materi sudah cocok dengan tingkat kompetensi berbahasa } \\
\text { Jepang peserta didik? }\end{array}$ & $91 \%$ & $8 \%$ \\
\hline
\end{tabular}

Berdasarkan hasil angket respon mahasiswa pada tabel di atas secara umum dapat diambil pengertian bahwa, hampir semua mahasiswa memberikan jawaban "Ya" sebagai tanda menerima dan setuju dengan model pendekatan Lesson Study dengan menggunakan materi ajar yang bersifat apresiatif. Meskipun ada mahasiswa yang memberikan jawaban "Tidak", tetapi jika dilihat prosentasenya sangat kecil jika dibandingkan dengan prosentase yang memberikan jawaban "Ya". Prosentase tertinggi jawan "Tidak" yaitu pertanyaan nomor 10 terkait kesesuaian format materi dengan besaran prosentase $8 \%$. Hal ini dimungkinkan mahasiswa yang memiliki kemampuan berbahasa Jepang kurang. Diprediksi mereka mengerti jawabannya tetapi tidak dapat menyampaikan dengan bahasa Jepang, akibatnya membuat peserta didik merasa sulit dan merasa materi tidak cocok dengan tingkat kemampuan berbahasa Jepang yang dimiliki.

Hal tersebut di atas dibuktikan dengan hasil angket terbuka, ketika diberi pertanyaan yang sama dengan model jawaban deskripsi, mahasiswa yang menjawab "Tidak" pada angket tertutup tersebut ada yang tidak memberikan jawaban. Sedangkan yang memberikan jawaban rata-rata mereka mengatakan "tidak bisa menyampaikan dalam bahasa Jepang", "kosa kata saya tidak cukup sehingga jawaban saya dalam bahasa Jepang tidak keluar", dan "sulit menyampaikan dalam bahasa Jepang". Tetapi ketika diminta untuk mendeskripsikan aspek positif dari model materi yang diberikan, mayoritas jawaban yang diberikan, "hal yang dibicarakan bisa ditemukan dalam kehidupan nyata", "kebetulan saya juga pernah mengalami", "materi mampu membawa saya seakanakan saya terlibat dalam permasalahan yang ada di materi”. Artinya materi yang diberikan dianggap sudah mampu memenuhi kebutuhan mahasiswa yaitu, materi yang sesuai dengan pengetahuan dan pengalaman hidup mahasiswa.

Terkait dengan penerapan model pendekatan pembelajaran dengan Lesson Study, mahasiswa memberikan jawaban uraian, "pendekatan ini memberikan 
kesempatan kepada kami untuk mengambil peran secara aktif dalam proses pembelajaran", "saya senang karena dengan pendekatan Lesson Study saya bisa belajar bekerja secara tim, sehingga kalau tidak tahu bisa bertanya kepada teman satu tim, karena kalau tanya ke dosen malu", "Lesson Study memberikan kebebasan berpikir, kebebasan untuk menyampaikan pendapat, dan memberikan kesempatan kepada kami untuk terlibat langsung dalam pembelajaran". Beradasarkan jawaban mahasiswa dari angket terbuka tersebut di atas maka, dapat diamabil pengertian bahwa mahasiswa dapat menerima dan dapat mengikuti kegiatan proses belajar mengajar melalui model pendekatan Lesson Study. Meskipun ada mahasiswa yang tidak memberikan jawaban tetapi jika dibandingkan dengan jumlah mahasiswa yang memberikan jawaban prosentasenya hanya mencapai $2 \%$ dari total jumlah mahasiswa. Hal ini terbukti ketika diadakan evaluasi dimana bentuk tes evaluasi ini ada tiga jenis yaitu berupa tes wawancara, tes percakapan, dan tes presentasi, 93\% mahasiswa dapat melakukan dengan baik dan dapat memenuhi aspek-aspek yang ditargetkan dalam rubrik penilaian. Hasil ini dapat digunakan sebagai bukti bahwa model pembelajaran Lesson Study yang didukung oleh materi ajar apresiatif dapat membantu meningkatkan kualitas PBM dan kompetensi peserta didik.

\section{Refleksi}

Setelah kegiatan pembelajaran selesai masuk tahap refleksi. Refleksi dibagi menjadi 2 yaitu refleksi hasil aktifitas belajar mahasiswa yaitu dengan melihat kembali hasil rekaman video yang bertujuan untuk melihat aktivitas mahasiswa selama proses belajar mengajar. Refleksi ini melibatkan semua tim peneliti dan mahasiswa serta dilaksanakan di luar jam pelajaran. Refleksi yang kedua ialah refleksi hasil kegiatan pengajaran yang bertujuan melihat aktivitas dosen dan mahasiswa selama proses belajar mengajar berlangsung. Refleksi yang kedua ini hanya dilakukan oleh tim peneliti saja tanpa melibatkan mahasiswa. Kedua refleksi dilaksanakan setiap akhir kegiatan proses belajar mengajar selesai.

Secara keseluruhan kegiatan refleksi memperoleh hasil sebagai berikut. Aspekaspek yang berhubungan dengan aktivitas mahasiswa, secara umum mahasiswa sudah aktif, sudah terjadi interaksi yang cukup baik. Keterlibatan mahasiswa dalam proses pembelajar sudah cukup baik meskipun masih ada sebagian kecil mahasiswa yang belum dapat secara maksimal terlibat penuh. Mahasiswa yang masih belum bisa terlibat secara penuh rata-rata dalam setiap pertemuan sama, artinya tetap personal yang sama. Mahasiswa ini nampak masih kurang termotivasi, dimungkinkan memiliki keterkaitan dengan masalah tingkat keterampilan berbahasa Jepang yang mereka dimiliki. Karena tingkat penguasaan berbahasa Jepang mereka termasuk rendah, hal ini menyebabkan enggan untuk terlibat dalam kegiatan pembelajaran. Keadaan ini semakin nampak pada tahap pelaporan hasil kerjasama dan pembahasan. Mereka ratarata kurang dapat terlibat secara penuh, cara menyampaikan hasil pun dengan membaca, sehingga pada saat ada pertanyaan dari kelompok yang lain mahasiswa kriteria ini nyaris tidak dapat memberikan jawaban. Kondisi mahasiswa seperti ini perlu mendapatkan perhatian dan perlakuan khusus dari dosen, terutama untuk pembimbingan agar jarak kesenjangan antara mereka dengan mahasiswa lain tidak semakin jauh. Mereka harus dimotivasi terus agar terlibat penuh dan perlu diyakinkan tidak boleh merasa ragu atau minder. Sedangkan mahasiswa lain yang memiliki kemampuan 
lebih khususnya yang menjadi satu kelompok, juga harus diberi pengertian agar teman yang kemampuannya kurang dibantu agar mereka juga dapat mengikuti aktivitas pembelajaran bersama dengan baik.

Aktivitas dosen berdasarkan hasil observasi dan hasil rekaman video menunjukkan bahwa, dosen telah mengelola kelas dengan cukup baik. Hal ini dibuktikan dengan model tempat duduk membentuk huruf $U$ sehingga antara mahasiswa dapat berhadapan dan dapat saling berkomunikasi. Penguasaan kelas oleh dosen juga sangat bagus, terlihat di saat dosen menjelaskan atau memberikan instruksi dosen tidak selalu mengambil posisi di depan mahasiswa, terkadang juga di belakan duduk mahasiswa atau disamping, tetapi pembicaraan tetap diarahkan pada hal-hal yang selalu disampaikan dengan power point dan ditampilkan di depan yang dikendalikan dengan pointer. Penggunaan media oleh dosen juga sudah bagus sehingga sangat mendukung kemudahan dalam penyampaian informasi. Upaya dosen untuk memotivasi mahasiswa juga menunjukkan upaya dosen yang sangat tinggi. Hal ini ditunjukkan dosen tak hentihentinya terus mendorong mahasiswa untuk turut terlibat dalam proses pembelajaran khususnya kepada mahasiswa yang memiliki tingkat kemampuan rendah. Mobilitas dosen juga sangat tinggi, dosen tidak pernah duduk selama PBM berlangsung, dosen selalu bergerak dan mengitari ke semua tempat mahasiswa berada. Sehingga semua sikap dan perilaku mahasiswa benar-benar dapat terkontrol dan terpantau dengan baik. Tetapi, dosen sering lupa akan alokasi waktu, sering waktu yang telah diberikan untuk satu kegiatan tertentu sudah terlampaui tetapi tidak sadar karena perhatian terlalu fokus terhadap pengamatan aktivitas mahasiswa. Sebagai akibatnya, sering kegiatan tidak tuntas sehingga, khususnya pada saat latihan percakapan, hanya sedikit kelompok yang mendapat kesempatan. Hasil ini digunakan sebagai bahan perbaikan pada kegiatan PBM berikutnya.

\section{Penutup}

Permasalahan pembelajaran salah satunya dapat diselesaikan dengan ketepatan pemilihan dan penerapan pendekatan pembelajaran dan karakteristik materi ajar. Model pendekatan lebih ditujukan untuk meningkatkan keaktifan dan peran peserta didik dalam PBM, sedangkan materi ajar lebih ditekankan untuk meningkatkan pemahaman peserta didik terhadap materi melalui pengalamannya sendiri. Penerapan model pendekatan dan materi ajar yang tepat akan membangun atmosfir PBM yang positif yang akan mengimbas pada peningkatan motivasi belajar peserta didik. PBM yang dibarengi dengan motivasi belajar peserta didik yang tinggi akan membantu memperlancar proses pembelajaran dan juga memberikan kontribusi yang tinggi terhadap ketercapaian tujuan PBM.

Lesson Study sebagai salah satu model pendekatan pembelajaran yang berorientasi pada peningkatan kompetensi melalui peningkatan kualitas PBM mampu meningkatkan peran dan keaktifan peserta didik selama PBM berlangsung. Keaktifan peserta didik dalam PBM sangat diperlukan karena sebenarnya peserta didiklah yang harus menjadi pemeran utama dan mengalami secara langsung aktifitas pembelajaran.Sehingga keberlangsungan dan kebersinambungan PBM tergantung pada seberapa jauh peran dan keaktifan peserta didik. Situasi PBM seperti ini menjadi salah satu ciri khusus yang dimiliki oleh Lesson Studykarena peserta menjadi perhatian dan prioritas utama.Kesempatan dan kebebasan terkontrol diberikan kepada semua peserta 
didik untuk terlibat dan berperasn aktif secara langsung dalam PBM guna membentuk karakter positif peserta didik.

Pembentukan karakter positif peserta didik melalui Lesson Study semakin mendekati titik kesempurnaan setelah didukung oleh materi ajar yang bersifat apresiatif. Melalui materi peserta didik dapat mengaktualisasikan potensi diri yang diperoleh melalui pengamatan, pengalaman, dan atau pemikirannya. Materi difungsikan sebagai perangsang awal untuk memancing agar peserta didik terbantu untuk mengungkapkan pengetahuannya yang tersimpan dalam memori selanjutnya diaktualisasikan secara lisan. Peserta didik akan menghubungkan rangsangan materi dengan pengetahuan yang diperoleh dari pengalaman dalam kehidupan nyata artinya, materi mampu membawa logika berpikiran peserta didik ke dunia nyata. Sehingga pemahaman peserta didik dikonstruksi melalui konsep yang lebih riel baik melalui pengamatan maupun keterlibatan langsung.

\section{Daftar Pustaka}

Brown, H. Douglas. 2007.Prinsip Pembelajaran dan Pengajaran Bahasa, Edisi Kelima. Pearson Education, Inc.

Fernandez, C. 2002. Learning from Japanese Approaches to Proffesional Development: The Case of Lesson Study. Jurnal of Teacher Education 53 (5), pp. 393405.

Gagne, Robert.M, Leslie J. Briggs. 1979. Principles of Instructional Design Second Edition. United States of America.

Hudson, T. 2007. Teaching Second Language Reading: Oxford Handbooks for Language Teachers. New York: Oxford University Press.
Inagaki, Satou Manabu. 1996. Jugyoukenkyuu Nyuumon. Iwanami Shoten.

James W. Stigler, Clea Fernandez \& Makoto Yoshida. 1996. Cultures of Mathematics Instruction in Japanese and American Elementary Classrooms, In: Teaching and Learning in Japan, Edited by Thomas P. Rohlen \& Gerald K. Le Tendre. Cambridge University Press.

Matoba, Masami. 2008. Jugyoukiroku no Saikousei to Jugyoushoyouin no Shucchou ni Kan Suru Jikken Kenkyuu. Nagoya Daigaku Daigakuin Kyouiku Hattatsukagaku Kenkyuukakiyou, 3, pp. 148-161.

Matoba, Masami. Sarkar Arani Mohammad. (2003). Jugyoukenkyuu o Kiso to Shita Kounaikenshuu to Kyoushi no Shishitsu no Kan Suru Kokusaikyoudou Kenkyuu (1). Iran ni Okeru Jugyoukenkyuu no Iten no Jirei. Nagoya Daigaku Daigakuin Kyouiku Hattatsukagaku Kenkyuukakiyou Dai 50 maki dai 1 gou, pp. 146-161.

Omstein, Allan C. Dan Daniel U. Levine. 1985. An Introduction to the Foundation of Education. Boston: Houghton Mifflin Company.

Sumardi, 2001. Buku Pelajaran Bahasa Indonesia Sekolah Dasar. Jakarta: Gramedia Pustaka Utama.

Sanjaya, Wina. 2006. Strategi Pembelajaran Berorientasi Standar Proses Pendidikan. Jakarta: Kencana.

Shin-Ying Lee, Theresa Graham \& Harold W. Stevenson. 1996. Teachers and Teaching : Elementary Schools in Japan and The United States. In: Teaching and Learning in Japan, Edited by Thomas P. Rohlen \& 
Gerald K. Le Tendre, Cambridge University Press, pp.177.

Subandi. 2008. Penerapan Model Pembelajaran Lesson Study sebagai Upaya Perbaikan Mutu Pendidikan Dasar (Implementasi di Jepang dan di Indonesia). Jurnal Pendidikan Dasar Vol. 9, No. 2.
September 2008. University Press Universitas Negeri Surabaya.

Yuwana, Setya. 2002. Problematika Pembelajaran Apresiasi Sastra dan Solusinya. Lembaga Penerbitan Fakultas Bahasa dan Seni Universitas Negeri Surabaya. 